\title{
Knowing the Unknowable Paul Piccone
}

\author{
Alan Sica
}

Piccone means pickaxe in Italian, which makes sense. (Sica means assassin's dagger, which does not.) We first met on a hot Kansas day in early September, 1977, and within 15 minutes he began to bury me in a storm of ritualized insults, as was his wont. Soon thereafter he told me I should work for his journal rather than wasting time on scholarship that would advance my sociological "career," a word he spoke with a punishing leer. He had driven the 290 miles from St. Louis to Lawrence in a stylish white 450SL roadster, which gave instant, shocking meaning to the cliché "Mercedes Marxist." I had just arrived there from Amherst, Massachusetts to begin my first tenurable job. The new "Kansas Telos Group," as we jocularly referred to ourselves, though with some pride, accompanied Piccone and other visiting Telos friends — could they have been Andrew Arato and Paul Breines? — to a declassé steakhouse on the east side of town. He offered me a ride in the shotgun seat of his convertible with the top down, even though the heat worked against a pleasurable trip. He asked me where and with whom I had studied, then explained with a scowl that no sociologist in Amherst knew anything worthwhile. He did grant, though, that the URPE group around Bowles and Gintis in the UMass Economics Department was pretty good, and that Norman Birnbaum had written one useful book, The Crisis of Industrial Society (1969). I had worked closely with the latter and had exploited the former, to the extent they would give me their attention, as I tried to disentangle the workings of global capitalism.

Each time he insulted me-he was 37 and I was 28, so he played the big brother, his birthright in his natal family - he would splutter, smile, and laugh, as if it were a joke, testing me to see if I would wither under his scorn. He spoke like a character from Farrell's Studs Lonigan or Pietro Di Donato's Christ in Concrete, only better educated and older than his years. The choice to me was clear: tolerate his abuse until he left town, or hit him forcefully in the nose. Yet after the first stream of unpleasantness, including attacks on my lineage, marital state, education, choice of theoretical interest, clothing, and hairstyle, after noticing that I was not laughing, he changed his tone of voice. Like a hustler, he began to solicit my help with Telos, explaining that any effort I expended doing sociology and trying to become tenured was prostitution, while any time I donated to his vision of what his journal should be would cause me to be smiled upon by Marx, Adorno, Horkheimer, Marcuse, and Benjamin. Not to mention Gramsci.

What Paul could not know, though much later I did mention it, was that I had been reading Telos at Logos Bookshop in downtown Amherst for several years, and buying issues as our pitiful domestic budget allowed. It had become the only irreplaceable journal in my autodidactic quest for theoretical clarity and political insight. This remarkable bookstore featured the complete Lenin in the Moscow edition with multiple copies of Volume 38 on Hegel's Logic; most of the Marx/Engels works in the East German edition; lots of Frankfurt School materials in various languages; and a slew of leftwing journals. It was relaxedly run by Zachary Cohn, who was a blessed figure among the bookish of that time and place. One December evening I trudged the two miles home in thick snow from Logos carrying a box Cohn gave me in which I nestled Theories of Surplus Value in the Moscow edition-which at $\$ 10$ for the clothbound edition seemed a luxurious bargain. The store catered to notables, like the very young Anson Rabinbach (of New German Critique, my second favorite journal) who one day very helpfully suggested I buy a 19th century copy of W. E. H. Lecky's precocious masterpiece on rationalism (I did not have the $\$ 7.50$ it cost.). He did not know me at all, but overheard the précis of my dissertation topic on irrationality and Weber, and wanted to help, which he surely did — even though as I recall he had little regard for Weber. Ever since Marcuse and Habermas had attacked Weber in 1964 at the Heidelberg centennial meeting, right-thinking people regarded him as a high bourgeois apologist, much inferior to the heroes of the Left. 
So by the time I met Paul, I had been feasting at his journal's table for several years, owned a complete set except for the chubby Vol. 6, and thought it a priori a great privilege and rare opportunity to meet him, even in the dusty byroads of Kansas (And dusty they were at that time.). When I peruse my shelves these 32 years later, and note my large collection of Marxology and other Telos-related materials, I cannot help feeling sorry for my own graduate students. Their enthusiasms are not any less worthy or promising than were ours then, but the intellectual atmosphere between about 1968 and 1976 grew out of a robust tradition, from Hegel to Habermas, that promised human liberation and enlightenment on a new scale, and with surplus profundity. Even in the midst of a dark economic era-48\% unemployed minority youth in Springfield, Massachusetts in 1975, and general unemployment at nearly 20\%-highbrow Leftist social thought yielded warmth and welcome mental relief, especially to Boomers. And this feeling of plausible liberation from darkness resided securely in successive issues of Telos (and New German Critique). It was, of course, a closet pleasure, since one's official education in sociology did not recognize these journals as existing, a situation that probably enhanced their appeal, their genuinely counter-cultural weightiness. If one's senior professors had no clue what was going on in these outlets of deep thinking, this was surely to the good.

In short, Paul Piccone, through his journal, was a primary agent working on behalf of heightened theoretical acuity, political savviness, and a liberating historical sense that was not available through any other means (at least in English). By his own estimate, he probably felt he and his few, dedicated confederates held a "lock on truth" which distinguished them from mainstream social science, feathering its nest while ignoring the cultural and societal tragedies that had inspired the Frankurt School and its American variant: the Telosers. That he habitually behaved "irrationally" along so many professorial axes, and that over time he became a tragic, noble figure of myth-the uncompromising Quixote of leftwing cultural and social theory—turned into an article of faith among the "critical theory" crowd, small but attentive. When he was denied tenure at Washington University, despite strong support from Daniel Bell, Habermas, and other luminaries, no-one who knew him well was surprised since he had failed the first test of the professoriate: to behave properly and show respect along rigid lines established by upper middle-class social norms. Like a Neapolitan tailor with a pressing deadline, he cursed, he fumed, he sprayed his impatience with mediocrity all around, and he did it naturally and regularly, as if everybody else were blinded by their small ambitions and could not perceive the truths that were so obvious to him.

Over a steak that Kansas afternoon, Paul asked if I had anything suitable for Telos, so I mentioned my nascent interest in global capitalism. He was skeptical about the value of this line of scholarship, but allowed that perhaps I could write a treatment of a major new book, Samir Amin's Unequal Development (Monthly Review Press, 1976). The prospect of publishing in Telos seemed too good to be true, and I set to work with passionate devotionyouthfully oblivious that hidebound university administrators would not be impressed with a byline in this little, leftwing journal, no matter how important it had become to me and a few others at Kansas. Somehow over the next few months, between teaching my first classes, finishing a 700-page dissertation, and writing other things, I made time to study Amin's book carefully-I even corresponded with Amin, who was in Dakar, Senegal—and produced a 30-page review-essay that I called "Dependency in the World Economy." My goal was to introduce Telos readers who might subscribe to "modernization theory" and "import substitution practices" to a somewhat new way of viewing the global economy, "dependency theory." I had been led to this by Stephen Resnick, one of the URPE economists at UMass, who regarded modernization theory as incorrect, and suggested I leave that camp entirely when I asked him for guidance.

Imagine my shock when in early 1978, Piccone rejected the piece as not being "critical" enough for Telos, betraying his peculiarly Gramscian lack of interest in serious political-economy. I had thought that by inviting me to write the essay, he had assured publication. Unperturbed, and convinced the piece had some small value, I sent it to the American Journal of Sociology at the University of Chicago, standard-bearer of the field. Supremely ignorant of disciplinary norms, I had no idea that AJS never accepts unsolicited review-essays, that in fact one must be a well-known scholar to be asked to write an essay for the journal, and that such works are often widely read and discussed even more than the standard articles. Shortly thereafter I heard from the book review editor at AJS. I was asked if I was in any way related to Amin or in his pay, and when I explained that I had never met him, they agreed to publish the essay without changing a word! It appeared in November 1978, and was for a good while my most widely discussed piece, even assigned as required reading for graduate students at the University of Michigan, so I was told by faculty there. Thus Piccone had won for me my first major publication in the top sociology journal simply by asking that I write a piece, then rejecting it out of hand.

One learned to forgive Piccone his catalogue of personal and professional defects for one simple reason: he was 
the real thing, the genuine article. If ever a man whom I have met lived exclusively for ideas, free of professional, familial, and personal vanities, it was he. He dressed and combed his hair like an Italian storekeeper-neat, fashionless, oblivious to hipsterism, yet without interest in money or personal advancement. Later I saw him as the modern incarnation of Vico, whose father ran a large bookstore in Naples, which is how and where the genius educated himself in all things-yet, like Piccone, was never able to gain a decent academic post. In the early 80 s my wife spotted a fat book on my shelf, Enzo Paci's The Functions of Sciences and the Meaning of Man (1972), and thereby chose Paci's first name for our second son. I had bought this expensive title because "phenomenological Marxism" and its mixture with psychiatry interested me, but would never have had access to Paci had not Piccone (and James Hansen) selflessly translated this 475-page tome for the Northwestern University Press series that educated so many of us. He told me that he did not ask for nor was offered any money for his work on this difficult project, which must have taken hundreds of hours over many months, including a 30-page introduction that was indispensable. Pushed to discuss the work, he would only say that Paci was important, and that "nobody else wanted to do the translation."

Working with Piccone was an exercise in contradictions. He seldom wrote letters, but loved to call, at home or office, and yell into the telephone about the next issue of the journal, how everything unrelated to the journal had to be dropped, including domestic duties, so that a mountain of work could be sent to him immediately, or surely within several days. Nothing one had written was ever good enough, no paper one edited had been done thoroughly enough — the Kansas Telos Group was sent manuscripts to review as part of our responsibilities to the journaland no amount of trouble taken on behalf of him and his various obsessions was ever acknowledged except in a backhanded way. Being the eldest of six sons left its mark on Paul, for good or ill.

And yet he did surreptitiously recognize one's work, and he did value it. I learned from third parties that for some years he would throw copies of my review-essays at prospective writers, and demand that they live up to the standard I had (unwittingly) set. From him personally I never heard a positive word. He sometimes made insane requests. He sent me Maurice Finocchiaro's Galileo and the Art of Reasoning (1980), a long, difficult, innovative work for which I had no preparation. Being young and “dutiful," I found Galileo's own texts and read them, then read other books which bore on the topic of Galileo's life and rhetorical style, spending several months in all, and then composed my essay. It was this one, so I heard, that Piccone would use as a hectoring device when prompting other reviewers to produce work up to the vaunted Telos standards. In all I wrote seven essays for Piccone between 1977 and 1988 (on Gadamer, Therborn, Jacoby, Austrian socialism, Mead, and Thomas Mann), each calling for a lengthy process of specialized knowledge-acquisition which had nothing to do with my other work. Piccone eventually became my hated drill sergeant from a parallel scholarly universe: every time he would send me an assignment, I would groan at the prospect of the mighty work it would require and the small reward it would bring. Yet, of course, by the time I had finished each essay, I had learned a great deal about matters that would otherwise have escaped me. The straw, though, that broke the camel's back was a request that I review several of Hans Blumenberg's books. Each weighed about ten pounds and totaled thousands of pages, so half-way through the project, I sadly threw in the towel, mostly because I was by then editing the ASA journal, Sociological Theory. Piccone kept asking me for the piece, of course.

When I needed support for early tenure at Kansas, he wrote a detailed account of my essays in Telos on sociology department letterhead from Memorial University of Newfoundland, where he had a temporary job. I will not quote much from the letter of October 22, 1981 (which I was not supposed to see, but somehow secured many years later), but had I read it then, I would have thought he was lying-despite the fact that he never lied about anything intellectual, so far as I could tell. He explained to the needling Kansas administrators that all Telos reviewessays were screened by himself, Paul Breines (book review editor), and also by one or two other "experts in the particular field" before they are accepted. "Sica's work has always been of the highest quality and has immediately attracted international attention.... h have received nothing but praise from as far as Iran and India for the work of his which we have published. What makes Prof. Sica's work extremely valuable..." and so on. He concluded his unconstrained praise with "Sica is presently one of the most promising young sociologists in the discipline." It's very good that I did not read the letter when it was written, as I would have thought too well of myself, and would also have suspected Piccone of duplicity. He told me I was wrong most of the time, wasting my talent on sociology. The man who yelled at me regularly by phone was not the same one, so it seemed, who composed this helpful encomium to a very young scholar.

Three years later I returned the favor, more or less, by agreeing to review Paul's superb monograph, Italian Marxism, in the leading review journal for sociologists, Contemporary Sociology (which, very strangely indeed, I now edit). I do not know why the editor asked me to review the book, but I could hardly refuse, and it was my good luck that the book was excellent on every count, as I indicated: 
Should you read only two books this year on Marxism as a vital intellectual, political presence, let this be one of them. (The other could be Russell Jacoby's Dialectic of Defeat [which I had reviewed for Telos]...virtually a companion volume to Piccone's though not designed as such.) With the decentered subject suffocating reflection and renewal, the culture industry anesthetizing everybody, and Left liberation a poor joke, Piccone's analysis of Hegelian-Marxian thought in Italy since the 1840 s legitimately renews hope that humanity might achieve its own salvation.

What made the book remarkably un-Picconean was its smooth, balanced, dense, Crocean flavor. All his posturing, fulminating, refusal to acquiesce to the ordinary or conventional disappeared, and in its place a fluid and solid work of Italianate scholarship was revealed. Either Paul restrained himself through uncharacteristic self-discipline, or a very fine copy-editor at the University of California Press removed his usual fire and brimstone. The results, however achieved, were excellent, and the book remains his lasting scholarly contribution.

A characteristic Piccone letter in my thin Telos files (he seldom wrote them) is from his office in St Louis, on Feb. 12, 1985. It reads as follows:

Dear Alan:

What the hell! You moved on me. I called your number-or better, the number that you gave me, and someone told me that you were gone elsewhere without a forwarding number. [ I had taken a visiting job at the University of Chicago for '84-85, and the people renting our home did not want to reveal our number there; one can only imagine their perplexity when Paul began yelling at them on the phone in his Italianate accent; they were extremely meek and pleasant people from western Ohio.]

At any rate, I am back in St. Louis and trying to put togegher [sic] the next issue. You will hear a lot from me during the next couple of weeks if you let me know your new number! [ I was truly buried in work, serving on the staff of the American Journal of Sociology, teaching full-time, writing, "doing Chicago" with my family, and going to lots of invigorating talks, so Telos was distant from my frame of reference at that point-none of which would have impressed or interested Paul in the least.]

What I need right away, before anything else, is that damn Offe piece that I sent you a couple of months ago. Did you shape it up? What has happened? [Perhaps because I was away, I never got the Offe article. Paul expected members of the editorial board to "clean up" pieces in translation by famous Europeans on a regular basis, which often required very substantial time, not to say temerity, in that most of the writers we were asked to "clean up" were much older, more famous, and more learned than were we. And often the lightly photocopied manuscripts were scarcely legible to boot.]

I'll ship out a newsletter within a week or so, along with my comments on your Elias paper... [Piccone regularly sent out harangues to the troops which he called "newsletters," but were in fact screeds telling us what we needed to do regarding Telos, and also chastising every example of stupidity he had read of late. He never responded to my Elias essay, which he chose not to publish, so I gave it to a small journal, which was again lucky for me. It was precisely that essay, "Sociogenesis versus Psychogenesis: The Unique Sociology of Norbert Elias," which began an elaborate epistolary friendship with Robert K. Merton. Had I published it in Telos, Merton would likely never have seen it, and I would have missed a lively, longterm intellectual friendship over the succeeding 20 years until Merton's death.]

Call me as soon as you can (\#314-776-6844)

Regards to the family,

Paul

Piccone's closing mention of my family meant something genuine and moving, even then, but surely more so now. During spring break, 1984, my wife and our two young sons braved the ice and snow to visit Piccone in St. Louis, responding to a long-standing invitation. His 1890 s robber-baron, gated-community mansion in what had long before been the nattiest part of St. Louis was as fascinating to us as his Old World domestic charm and solicitude. Around my family he became a different man, asking what we needed by way of food or sleeping quarters, and humoring our sons' inquisitiveness. Never before or since had we as a family spent the night at a professional colleague's home, so it was entirely experimental on our part, and given Piccone's irascible persona, we did not know what to expect. As I recall, the home was equipped with an elevator, original to the house, which added to its anachronistic charm. In truth, it was a dark, drafty, spooky barn, but Paul's sincere interest in our comfort and welfare brought it to life. So far as I could tell from available evidence he was there alone most of the time, in a domestic space which in its heyday probably housed a dozen people comfortably.

Yet aside from all that, my fondest memory came quite late that night. For some reason, despite having made 
the 6-hour drive under exhausting conditions, I was not sleepy, and neither was he, so around midnight we sat in his Telos office on the second or third floor of the mansion, chatting easily about scholarly matters when he paused and looked at me from his swivel chair, smiled a little and said, "So, Sica, where are the ideas? Who's got the new ideas?" Perhaps this sort of pregnant moment occurs regularly among other intellectuals, but it was so rare for me that I have recalled it often as the hallmark of Piccone's personality, and a summing up of his life's meaning. That I had no ready answer for him illustrated in Platonic form what he wanted me to understand: if I could not easily identify the thinkers who would provide "us" with the next round of important notions, then perhaps I would have to dream some up myself. He would have made a great sports coach had he not been so interested in thinking, writing, the printed word, and what Elias called "the civilizing process." In my experience, he was unique. 
